\title{
Relative Impact of Various Taxes on Poverty in Ghana
}

\author{
Sugar Emmanuel Frank Kordzo Adukonu ${ }^{1}$ \\ Grace Ofori-Abebrese ${ }^{2}$ \\ 1, 2 Department of Economics, Kwame Nkrumah University of Science and Technology \\ Kumasi, Ghana; Email: seefkasugar@hotmail.com,ofori35@yahoo.com
}

\section{Doi:10.5901/mjss.2016.v7n3p150}

\section{Abstract}

Poverty and inequality are tortuous manifestation based on a grid of interconnecting social, demographic, economic and political elements which are source of worry to society. Understanding their nature and effect is essential in functioning policies to address them. Taxation which is one of the sources governments mobilize revenue to address issues affecting the poor and society also have effect on poverty and inequality. This study investigates the effect of Ghana's tax policies on poverty. The study employed the Johansen cointegration estimation techniques using annual time series data from the period 1984 to 2013. The results show that increase in indirect tax policies worsen poverty level in Ghana. However, direct tax policies and remittances have mitigating effect on poverty. Considering the agrarian structure of the economy, reducing export taxes will promote activities in the export subsector.

Keywords: Tax Policy, Poverty, Ghana

\section{Introduction}

One of the main ingredients to the development process of every nation is revenue mobilization. Ghana and other developing nations in general are battling with several challenges in generating enough revenue to finance their developmental programmes due to weak tax systems. This loss of revenue hinders government capacity to provide social service to help the poor.

Though, tax form a huge part of government receipts in developing nations, in an attempt to raise revenue through taxation, policy makers are question to do so equitably, progressively and effectively if their aim is to achieve reduction in poverty and democratic governance (Balstra and Mosioma, 2014). According to Musgrave and Musgrave (1989), equitability of the tax system which call for each taxpayer to contribute their fair share to government spending, demands a distribution of the tax burden in line with the economic capacity of the tax payer. This implies that the rich bears a higher burden of the tax. When equitable, progressive and efficient tax system is achieved, the poor benefit; in that the cost of provision of essential services such as quality health care, education, transport services and good roads are borne by the rich. This also ensures economic growth and development which can be considered as pro-poor.

According to Bird (2004), Kefela (2009) and Franzsen (2012), developing nation like Ghana is perceived as not able to achieve equitable, progressive and effective taxation due to the influx of informal sectors, low levels of literacy and corruption, inadequate salary structure for public servants, inadequate communications, deficient judicial systems, and firmly held interests against radical reforms among others. Kayaga (2007), asserted that while the less developed countries are facing numerous tax policy challenges in their attempt to establishing efficient tax systems, their developed counter-parts have made a tremendous gain in improving their tax policy systems over the years.

Ghana recognized that the surest way to develop is to reduce poverty which have been a sting to her economic development and also create the enabling environment for private sector to strive. This leads to the formation of various policies such as Vision 2020, Growth Poverty Reduction Strategy (GPRS) I and II and Ghana Shared Growth and Development Agenda (GSGDA) I and II, all aimed at economic growth and poverty reduction. These policies aimed at mobilizing resources for rapid economic growth by: a) reducing poverty and increasing employment opportunities as well as incomes, b) improving the general well-being of the citizens as a result of inequality reduction, c) achieving balanced economy, middle-income status and standard of living and d) increasing food production and processing of raw materials into finish goods as well as job creation among others.

The main focuses of all these policies are to enhance economic growth, infrastructure development, human development, rural and urban development and ensure enabling business environment. Although Ghana has achieved its 
middle income status before the 2020, poverty still remains high. During the periods from 1991 to 2013, poverty has been reduced significantly from $51.7 \%$ to $24.2 \%$ using upper poverty line of $\mathrm{GH} \$ 1,314$ per adult per year. This implies that about 6.4 million Ghanaians are poor (Ghana Statistical Service, 2014). The continuous pervasiveness of poverty in Ghana has raised questions of whether the challenge is about implementation of policies or raising the needed revenue domestically for development activities and poverty reduction.

As a result of low revenue mobilization through taxes for development projects, the less developed nations try to use alternative means to achieve economic growth. One of such means is foreign direct investment. Developing countries in their attempt to attract more foreign investment give attractive tax holidays to foreign companies from where they could have generated huge revenue. These tax exemptions lead to huge revenue loss to most developing countries. According to Baafi (2014), the 2013 tax exemptions in Ghana is in the region of USD \$923 million and that of 2014 is in the region of USD $\$ 1$ billion. Actionaid, (2014) also indicated that Ghana losses close to USD $\$ 1.2$ billion annually through tax incentives. The report also stated that in 2011 and 2012, the country lost an estimated amount of USD\$90 million in the mining sector alone as a result of stability agreement while the loss in the oil and gas sector was estimated at USD \$70 million in the two years due to ambiguous tax law which could not be fully applied as a result of varied interpretations. While the government gives these mouths' watering incentives to foreign companies who end up repatriating the proceeds to boost the economy of their respective countries, the little subsidies enjoyed by host countries are being removed one by one with others such as subsidies in the petroleum sector being replaced with taxes. The result is that the poor Ghanaians are heavily taxed to compensate for the loss of revenue through the tax incentives making it arduous in the fight against poverty in the country.

In addition, the large nature of the informal sector in Ghana and other developing nations, makes it extremely difficult to raise tax revenue through direct tax system. This compelled policy makers to depend laboriously on indirect taxes to finance development interventions. For example, VAT which was introduced in 1998 at initial rate of $10 \%$ to replace sales and service taxes charged at the rate of 15\% at the time has since witnessed some increments from $10 \%$ to $12.5 \%$ to $15 \%$ and currently $17.5 \%$ among other indirect taxes such as import levy, and custom duties. In the 2015 budget statement presented to the Ghanaian Parliament by the Minister of Finance and Economic Planning on $19^{\text {th }}$ November, 2014, a bill to impose a general petroleum tax of $17.5 \%$ on selected petroleum product was also introduced and passed that same day. This new tax policy took effect the following day $20^{\text {th }}$ November, 2014. Taxing petroleum products has been seen as effective and efficient means of raising revenue and it is expected to yield USD $\$ 482$ million by December, 2015.

According to Barro et al. (1995), both savings and investment are reduced when tax rates are increased or remain high. Financing government expenditure through taxation affects household budget constraint. For example, a high direct tax reduces the purchasing power of the working class and therefore serves as a demotivation for people to work with its repercussion for economic growth. On the other hand, high indirect taxes such as VAT increase the cost of goods and services and reduce the quantity of those goods that can be purchased. In addition, all indirect taxes are transferred to consumers who include the poor segment of the society. This could reverse the government agenda of reducing poverty to its minimum. The question to ask is can these tax policies of Ghana be pro-poor? The main focus of this study is to find out whether the tax policies of Ghana can be pro-poor. Thus, looking at the effect of tax policies on poverty and whether indirect taxes have higher impact on poverty than direct taxes. This study aimed at providing empirical evidence for policy makers and tax authority to consider in tax policy decision making and poverty reduction strategies as well as help stimulate the development agenda of the nation.

\section{Literature Review}

\subsection{Theoretical review}

Governments all over the world have responsibility towards its citizenry and the international society. These responsibilities require resources to perform them. One major source of these resources is taxation. According to Chinweike (2010) and Kumar and Mittal (2002), taxation is imposition of compulsory levy by government of a country or its appropriate agent. According to Cobham (2005) and Oyewo (2013), tax policies are capable of being used as fiscal policy tool to shape an economy and its long term goal in developing nations to address the question of distribution. Gordon and Wilson (1999), Kumar and Mittal (2002), Moore and Schneider (2004), Cohn (2007), Dadkhah (2009) and Romer (2012) noted that tax policies are used to manage demand and correct market failures, enhance governance and poverty reduction either directly or indirectly through redistribution of income and establishment of stronger fiscal contracts in poorer countries, shift resources from citizens to the state, curtails purchasing power of the individuals and 
affects productivity and investment. They noted that because the poor uses their income to acquire the basic life necessities to keep their souls and body together, they bitterly felt the outcome of tax policies than their rich counterparts who spend their income on luxuries.

In literature, experts on the filed such as (Sen, 1997, Sen 1999, Subramanian, 1997, Grusky and Kanbur, 2006, UNDP, 1990; Streeton et al., 1981 and Lipton and Ravallion, 1993 as cited in Handley et al., 2009) define poverty by using headcount of the population who fall below a predetermine poverty line base on income or consumption, or in terms of level of consumption/income to other dimensions such as capability, basic needs, and human development approaches. World Bank (2000) also defines poverty as "pronounced deprivation in well-being" and define well-being as command over resources to meet one's basic needs. Currently, the World Bank defines extreme poverty as living on less than US $\$ 1.25$ per day (purchasing power parity terms) and moderate poverty as living on less than US $\$ 2.00$ or US $\$ 5.00$ a day. Ghana Statistical Service on the other hand, defines poverty as lack of access to asset, services and human development, and consumption poverty (proportion of the population whose standard of living falls below a defined consumption basket represented by a poverty line). Ghana set poverty line at $\mathrm{GH} \$ 792.05$ per adult per year as the lower poverty line and $\mathrm{GH} \$ 1,314.00$ for the upper poverty line as at January, 2015.

Studies by Cleveland (2014), Brown (2011), Rich (1995) and Solow (1959) revealed that even though economic growth has significant impact on poverty reduction, when poverty is not eliminated or reduced, it can have grave consequences on growth. These studies show that individuals living in poverty experience poor health and are vulnerable to chronic diseases and disabilities, low life expectances and lower education which limit their ability to contribute to productivity and growth of the economy. Thus, higher poverty impacts negatively on economic growth due to under development of human capital and spending of societal or public money on non-capital investment. For example, Brown (2011) noted that high rate of poverty causes United States billions of dollars annually, weakens the middle class who are the engine of the economic growth, weakens the long-term competitiveness and democracy of the US, hinders the individuals' mobility, denies communities access to the American dream in those communities where poverty declines saw $\$ 7,000.00$ increase in family income as compared to communities where there was no reduction in poverty.

However, other studies such as Danielson (2001), Hull (2009) Kraay (2003), Pernia (2003), Ravallion (1997, 2001 and 2004) noted that growth actually benefit the poor. And that growth in the rural areas, agricultural and other productive sectors benefit the poor more than growth in the urban sector. They, however, noted that when inequality is high, the poor benefit less from growth. This implies that, for any country to achieve pro-poor growth, growth must be accompanied with reduction in both poverty and inequality.

\subsection{Tax policies in Ghana}

Tax policy in Ghana is a decision by government about what tax to impose and what categories of people are to pay a particular tax. Musgrave and Musgrave (1989) noted that, in designing a tax policy, consideration have to be given to the requirement of equity in distribution burden, the goal of the nation's macro policy, efficiency in the usage of resources and ease of administration. The first major tax policy decision of Ghana was taken in 1943 by the then British Colonial Masters which saw the introduction of income tax under the income tax ordinance (no. 27). This was after the failure of the Poll Tax Ordinance of April 1852 which was meant to raise fund for roads and schools. Under the poll tax, every man, woman or a child residing in districts under the British control were to pay one shilling per year. According to Abdallah (2008), the money raised were used to finance the increasing cost of British Administration than what it was meant for. Since then, there have been several amendments which include Income Tax ordinance of 1952, Act 68 of 1961, Act 178 and 197 of 1963 and Internal Revenue Act, 2000 (Act 592) among others. The Act 592 was to consolidate all the fragmented income tax laws in one. There have been several tax policies which saw the introduction of new taxes over the years. For example, another tax policy in 1995 saw the introduction of the Value added Tax which was repealed later that year and was re-introduced in 1998 under the VAT Act, Act 546 of 1998. This has also been replaced with VAT Act, Act 870 of 2013. It has become almost automatic that in every budget presentation to the parliament of Ghana, a new tax policy is introduced as amendment to the existing tax policies or by introducing a new tax or a specific tax. For example, the 2015 budget statement introduced a general petroleum tax of $17.5 \%$ on selected petroleum products.

\subsection{Empirical literature}

Studies have been conducted in this area with varying conclusions on how taxation and tax policies changes affect relative wealth and poverty. Auerbach (1996) in exploring why there are so many unanswered questions about the economic impact of tax reforms shows that there is a complex relationship between taxation, poverty, income distribution 
and economic growth. This results from taxation policies in developing nations which are influenced by different tax principles and theories, political and private interest. These tax policies are driven largely by the macroeconomic concerns of government while business concerns are the efficiency of the tax system or policy.

Bird and Zolt (2011), Duclos et al (2008) and Mabugu et al (2014) employed various methods in analysing the impact of dual income taxation and tax policy changes in developing nations including Mexico and South Africa on the poor and noted that unlike the developed nations, developing nations obtain a substantial portion of tax revenue from consumption taxes rather than income taxes which have implications for poverty and inequality. Their studies noted that the application of consumption taxes such as VAT on consumable goods with progressive subsidies on some categories of these goods or with strong welfare policies have a promising effect on poverty with outcomes that can be considered as relative or absolute pro-poor. Their studies further added that when consumption taxes are marginally increased on many groups of the consumable goods, these would also be considered as absolute pro-poor.

Mabugu et al. (2014) and Cororaton and Cockburn (2007) employed computable general equilibrium microsimulation techniques to assess the impact of pro-poor tax policy changes and trade reforms on poverty in South Africa and Philippines. Their studies noted that reduction in VAT and tariff cut through trade reforms, would result in a fall in consumer prices, compensated by increase in direct taxes which hit the non-poor. Hence a reduction of poverty and inequality while economic growth is boosted substantially.

Sehili and Wodon (2008) adopted a simple tax incidence analysis technique to investigate the potential impact of indirect tax reforms in Niger on the poor and concluded that the absorption of minimum increases in prices of goods consumed by low income segment of the population brought about by imposition of taxes is difficult. The study therefore proposed that government in the developing nation should consider other options of raising tax revenue which do not have much impact on the poor segment of society.

Amir et al. (2013) in their study on the impact of Indonesian income tax reform on key macroeconomic variable concluded that the reform brought about a marginal reduction in poverty incidence. However, households in the upper income blanket benefited more than those in the lower income blanket resulting in higher income inequality.

OECD (2012) investigated the role of taxes and transfers in income inequality and growth in 34 countries and posited that overall income inequality in all member countries were reduced through tax policy initiatives and transfers. Other studies by Prasad (2008), Okner (1975) and Caminada et al. (2012) also noted that the impact of tax policies and transfers on income redistribution are significant. For example, Joumard et al (2012) hinted that in OECD countries, poverty measured after taxes and transfers was 55\% lower than before taxes and transfers for the OECD average.

Quartey et al (2007) explored the trade-growth relationship and its implication for poverty in Ghana by employing computable general equilibrium model. The study concluded that the incidence, depth and severity of poverty in Ghana and other developing countries could be reduced by eliminating import and export taxes. Bhasin and Annim (2005) also investigated increasing VAT to compensate for elimination of import and export taxes, in Ghana and noted that the reduction in import taxes and increase in VAT lead to domestic consumers to substitute domestic goods with imported goods. This resulted in factors shifting to productive sectors resulting in increased household income and government revenue and $3.02 \%$ reduction in poverty.

\section{Methodology}

\subsection{Data source}

Secondary data span 1984-2013 was used for the study. The tax data were obtained from Institute of Statistical, Social and Economic Research (ISSER) publication on Policies and Options for Ghanaian Economic Development (1997), Ministry of Finance, Ghana Revenue Authority, Bank of Ghana website and World development indicators of the World Bank (2014). The per capita consumption was computed by the researcher from the World Bank's world development indicators by dividing the final household consumption expenditure by the population. The personal remittances received data were also obtained from the world development indicators of the World Bank.

\subsection{Model specification}

The study uses household per capita consumption as a proxy for poverty. Various researchers such as Davis (2003); Moche et al. (2014); Karlan and Thuysbaert (2013); and Pinkovsky and Sala-i-Martin (2014) have demonstrated in their work that household consumption per capita is a good proxy for poverty in that it covers all purchases made by resident household and appears to be more closer to the mean of the distribution of the poor. Taxes increase the cost of 
household consumption expenditure thereby reducing the relative wealth retained by the individual. The study estimates how changing the proportion of total tax revenue collected from four tax categories impact on household per capita consumption expenditure and for that matter poverty. Studies have also indicated that it is not the amount of taxes imposed on the citizenry by the state that have a greater impact on per capita GDP and by extension, per capita consumption, rather it is the relative changes in the various tax types which permit the state to raise some funds for development while allowing the citizen too to retain some wealth (Myles, 2009 and Arnold, 2008). The model specification follows argument by researchers such as Mabugu et al (2014), Bhasin (2011), Dartanto (2010) and Ackah and Ayertey (2012) who argued that the various taxes reduce the relative wealth of the individual and therefore have consequences for poverty. The study controlled Personal Remittances Received as an economic variable. The model is therefore specified as:

$$
P C C=f(T D G, T I P, T I M, T E M, P R R)
$$

Equation (1) is expressed in econometrics equation below:

$$
P C C_{t}=\beta_{0}+\beta_{1} T I P_{t}+\beta_{2} T D G_{t}+\beta_{3} \text { TIM }_{t}+\beta_{4} T E M_{t}+\beta_{5} P R R_{t}+v_{t}
$$

Where PCC is per capita consumption, $\beta_{0}$ is a constant, PRR is personal remittances received, TIP is taxes on income and property, TDG represents taxes on domestic goods and service, TIM is taxes on import, TEM is taxes on export and $v_{t}$ is a white noise. The rest of the betas represent the coefficients of the independent variables and helps to determine how much the independent variables affect the dependent variable in the study.

Equation (2) is transformed into natural log as

$$
\ln P C C_{t}=\beta_{0}+\beta_{1} \ln T I P_{t}+\beta_{2} \ln T D G_{t}+\beta_{3} \ln T I M_{t}+\beta_{4} \ln T E M_{t}+\beta_{5} \ln P R R_{t}+v_{t}
$$

Transforming into natural log helps to estimate the variables in the same form and make the interpretation of the results better and easy as well as reduce heteroscedasticity.

Table 1. Expected signs of the independent variables

\begin{tabular}{|l|l|l|}
\hline Variable & Theoretical / empirical basis & A prior expectation \\
\hline $\begin{array}{l}\text { Taxes on Income \& } \\
\text { Properties }\end{array}$ & Mabugu et al (2014) and Immervoll et al (2006) & Varied (Positive or negative) \\
\hline Taxes on Domestic Goods & Mabugu et al (2014), Makdissi et al (2008) and Emini et al (2005) & Positive \\
\hline Import Taxes & Dartanto (2010) and Bhasin (2011) & Positive \\
\hline Export Taxes & Ackah \& Ayertey (2012), Bhasin (2011), War (2002) and Nogues (2008) & Varies (Positive or negative) \\
\hline $\begin{array}{l}\text { Personal Remittances } \\
\text { Received }\end{array}$ & $\begin{array}{l}\text { Gupta et al (2007), Devkota (2014), Acharya \& Leon-Gonzalez (2013) } \\
\text { and Imai et al (2014) }\end{array}$ & Negative \\
\hline
\end{tabular}

\subsection{Estimation techniques}

The stationarity property of the variables in our model were examined using Dickey-Fuller Generalize least Squares (DFGLS) and the Phillip Perron (1988) unit root test.

The Error Correction Model (ECM) is used to estimate the parameters in Equation (3). This technique was employed because most of the variables specified in the model are expected to be non-stationary at the levels. In such a situation using OLS to estimate the coefficients would lead to spurious result which would have implication on prediction. Again, as the study focused to examine both the short and long run responds of poverty to various taxes, the alternative way to examine the dynamics is through the error correction mechanism. Specifically, the study employed the Johansen cointegration test and the vector error-correction model (VECM) which is fundamental for the study given the stationarity results discussed in the next section.

\section{Results and Discussion}

\subsection{Test for stationarity}

The study tested for stationarity of the endogenous variable within the framework of Dickey-Fuller Generalized Least Square (DFGLS) and Phillips-Perron (PP) unit root tests. Table 2 shows the results of the stationarity test. 
Table 2: DFGLS and PP Unit Root Test Results

\begin{tabular}{|c|c|c|c|c|c|}
\hline \multirow[t]{2}{*}{ VARIABLES } & \multicolumn{2}{|c|}{ DFGLS TEST TAU stat } & \multicolumn{2}{|c|}{ PHILLIPS - PERRON TEST } & \multirow[t]{2}{*}{ ORDER OF INTGN } \\
\hline & \multicolumn{4}{|c|}{ PANEL A: LEVELS } & \\
\hline $\operatorname{InPCC}$ & 0.275 & -2.539 & -1.334 & -2.008 & $?$ \\
\hline $\operatorname{lnTIM}$ & 0.731 & -1.825 & -1.982 & $-3.573^{*}$ & $?$ \\
\hline InTEM & -0.275 & -2.386 & -1.299 & -3.212 & $?$ \\
\hline InTDG & $-2.784^{\star \star *}$ & -2.986 & -2.384 & -2.436 & $?$ \\
\hline InPRR & $-2.434^{\star \star}$ & -1.937 & -1.554 & -1.951 & $?$ \\
\hline $\ln T I P$ & 0.456 & -2.384 & -1.485 & $-3.342^{*}$ & $?$ \\
\hline \multicolumn{6}{|c|}{ PANEL B: FIRST DIFFERENCE } \\
\hline $\operatorname{InPCC}$ & $-3.488^{\star \star \star}$ & $-3.469 * \star$ & $-4.981^{* \star *}$ & $-5.285^{\star \star \star}$ & $I(1)$ \\
\hline $\ln T I M$ & -1.939 & $-3.044^{*}$ & $-5.657^{\star \star *}$ & $-5.735^{\star \star *}$ & I (1) \\
\hline InTEM & $-2.667^{\star \star \star}$ & -3.022 & $-6.853^{\star * *}$ & $-6.674^{\star \star *}$ & I (1) \\
\hline InTDG & $-3.485^{\star \star \star}$ & $-3.820^{\star * *}$ & $-4.496^{\star \star *}$ & $-4.429 * \star *$ & I (1) \\
\hline InPRR & $-5.859 * \star *$ & $-6.923^{\star \star *}$ & $-4.808^{\star \star *}$ & $-4.785^{\star \star *}$ & I (1) \\
\hline InTIP & $-2.165^{\star}$ & -2.709 & $-3.769 * \star \star$ & $-3.746^{\star \star}$ & $I(1)$ \\
\hline
\end{tabular}

The results from both Dickey-Fuller Generalised Least Squared (DFGLS) and the Philips-Peron (PP) tests show that none of the variables were stationary at the levels. Thus, the null hypothesis that there is unit root and therefore the series are non-stationary has been accepted for all the series under examination. The first difference was therefore applied to investigate whether they are integrated of order one (I (1)). The result is shown in the second segment (Panel B) of table 2. When the first difference was applied, the results proved that all the variables were integrated with order one: I (1) under the application of both Phillips-Perron (PP) and Dickey-Fuller Generalized Least Square (DFGLS) unit root test techniques. Therefore, stationarity of the series at first difference has been accepted implying that all the series are integrated of order one: (I (1)).

\subsection{Test for long-run relationship}

The Johansen cointegration was used to test for the long-run relationship between the independent variables and per capital consumption. The result (Trace and maximum eigenvalue) cointegration test is presented in table 3.

Table 3. Johansen Test Results for Cointegration

\begin{tabular}{ccc}
\hline \multicolumn{3}{c}{ Unrestricted cointegration Rank Test (Trace) } \\
\hline \hline Hypothesized No. of CE(s) & Trace Statistics & 0.05 Critical Value (trace) \\
\hline None & 99.20518 & $95.75366^{* *}$ \\
At most 1 & 67.20547 & 69.81889 \\
At most 2 & 38.71391 & 47.85613 \\
At most 3 & 19.14657 & 29.79707 \\
At most 4 & 8.077172 & 15.49471 \\
At most 5 & 2.548882 & 3.841466 \\
\hline \hline Unrestricted cointegration Rank Test (Maximum Eigenvalue) \\
\hline \hline Hypothesized No. of CE(s) & Max eigenvalue & $\mathbf{0 . 0 5}$ critical value(Max) \\
\hline None & 31.99971 & 40.07757 \\
At most 1 & 28.49156 & 33.87687 \\
At most 2 & 19.56734 & 27.58434 \\
At most 3 & 11.0694 & 21.13162 \\
At most 4 & 5.528286 & 14.2646 \\
At most 5 & 2.548885 & 3.841466 \\
** indicates rejection of the null hypothesis at 5\% level. &
\end{tabular}

The maximum eigenvalue results in the second segment of Table 3 shows that there is no cointegration so the null hypothesis that there is no cointegration is accepted. However, the trace statistic result in the upper segment shows that 
there is cointegration at $5 \%$. The implication of the trace result is an acceptance of the alternative hypothesis.

This study therefore used the trace statistics and concluded that there is cointegration since the trace statistic at $5 \%(99.20518)$ is higher than the critical value of (95.75366). Thus the result revealed a stable long run relationship between the variables under study.

\subsection{Estimation of coefficients}

The estimated output as extracted from Eview 7 for both long-run, error correction and short-run are presented in tables 4 and 5.

\subsection{Long Run VECM estimated result}

The results from Johansen normalization estimation about the long-run relationship between Poverty, Tax policies and Personal Remittances Received as extracted from Eview 7 is presented in table 4 and is discussed below.

Table 4. Estimated Long-Run Results from VECM

\begin{tabular}{cccc}
\hline \hline $\begin{array}{c}\text { Dep. Variable } \\
\text { LNPCC }\end{array}$ & Coefficient & Std. Error & t-statistics \\
\hline CONST & 0.430640 & & \\
InTIP & -1.552784 & 0.57371 & $-2.70658^{\star \star \star}$ \\
InTIM & 1.994865 & 0.57608 & $3.46282^{\star \star \star}$ \\
InTEM & 0.466237 & 0.10640 & $4.38200^{\star \star *}$ \\
InTDG & 0.286559 & 0.18767 & 1.52689 \\
InPRR & -0.327243 & 0.09845 & $-3.32398^{\star \star \star}$ \\
\hline \hline
\end{tabular}

NOTE: "*; **; and ***" shows 10\%, 5\% and 1\% level of significance.

The long run estimated results show that the coefficient of tax on domestic goods and services (LNTDG) is positive but insignificant (thus, $\beta_{2}=0.286559$ ).

The coefficient of Import tax policy InTIM ( $\left.\beta_{3}=1.994865\right)$ is positive and significant at one percent (1\%) with an elastic effect. The implication is that a unit increase in import taxes results in 1.99 increases in poverty. This implied that import tax policy in Ghana is anti-poor. The result is not all that surprising because the Ghanaian economy is basically import dependent where almost every item from toothpick, matches, fish, rice to industrial materials are imported with insignificant component of goods consumed produced locally. Okine (2014) reported that Ghana imported between US $\$ 200$ million and US $\$ 400$ million worth of rice every year. Taxes imposed on these imported goods definitely hurt the poor segment proportionately more than the rich. Thus, increase in import taxes has a deteriorating effect on poverty in the long-run. The result is in conformity to the findings of Leith et al. (2003) and Dartanto (2010) who argued that increase in import tariffs hurts all workers groups and therefore worsen poverty. Bhasin (2011) also argued that eliminating import tariffs on both industrial and agricultural goods reduce the incident, depth and severity of poverty and therefore improve the poverty conditions in Ghana. Bhasin (2011) and Corong (2008) further argued that, when the import taxes are eliminated, producers benefit from relatively low price inputs for production thereby driving cost of production down. While consumers on the other hand also benefit from availability of variety of goods and the spill over effect of the backward and forward inter-sector linkages.

The coefficient of Export taxes $\beta_{4}$ is positive and significant at $1 \%\left(\beta_{4}=0.466237\right)$. The consequence is that one percent increase in export tax results in $0.47 \%$ increase in poverty and thereby worsening the pride of the poor. This may be so because majority of Ghanaian exports are agricultural based. Increasing taxes on such products means less export and therefore less revenue to farmers and those employed in the export subsector. Warr (2002) argued that export taxes on agricultural based products depress wages of unskilled labour and therefore have undesirable consequences on poverty. From another perspective, Ackah and Ayertey (2012) found that a reduction on export taxes on industrial products increase the composite agricultural prices which tend to worsen the poverty condition. However, the industrial export form insignificant proportion of Ghana's export. For example, between 2009 and 2013, the industrial export as a percentage of merchandize export averaged $15.15 \%$ while that of agricultural or food was $50.15 \%$. Implying increase of export taxes would lead to worsening poverty in the long run since a greater proportion of Ghana's export is mainly agricultural which is dominated by the poor. 
The effect of taxes on income and properties (InTIP) is negative in the long run and significant at one percent (1\%): That is $\beta_{1}=-1.552784$. This means that a percentage increase in direct tax policy rate would result in $15.52 \%$ reduction in poverty. This is so because by practice and law, the poor are exempted from the payment of direct taxes in Ghana. By Ghana's income tax policy, those who earn the first annual income of GH\$1,584.00 is tax free, the next GH\$792.00 is charged $5 \%$. The next $\mathrm{GH} \$ 1,104.00$ at $10 \%$ and the next $\mathrm{GH} \$ 28,200.00$ at $17.5 \%$. This gives a total of $\mathrm{GH} \$ 31,680.00$. Anything in excess of this attracts a rate of $25 \%$. This then exempt the poor from the payment of direct taxes since the Ghana poverty line (extreme poverty line is GH\$792.05 per adult per year and the upper poverty of GH\$1,314.00 per adult per year) fall within the tax free bracket. These taxes when collected are used to provide social facilities such as hospitals, schools, capitation, and Livelihood Empowerment Against Poverty (LEAP) which benefit the poor. This result confirms Mabugu et al. (2014) and Son (2003) who observed that direct taxes hurt the rich proportionately more than the poor. Son (2003) however, hinted that imposing direct taxes on income from farm land rent and farm income would negatively hurt the poor. Thus, tax on income and property are pro-poor and useful for revenue mobilization.

Consistent with theory and empirical studies, personal remittances received (InPRR) have a negative but significant impact on PCC at one percent (1\%) significance level. Thus, a 1\% rise in personal remittances received increases standard of living and therefore reduces poverty in the country. Gupta et al (2007) and Devkota (2014) found that private transfers in the form of remittances have a positive direct mitigating effect on poverty and also promote financial development and capable of reducing poverty by $20 \%$. Their study further argued that the remittances transfer purchasing power from relatively wealthy segment to the poorer members of the family and community which smoothen consumption, provide working capital and reduces poverty. The policy implication is that government can use deliberate policy initiatives to encouraged transfer of resources from the affluent segment of the society to the relatively poorer segment in the form of remittances as poverty reduction strategy.

\subsection{Short-run results of the VECM model}

The dynamics of the short-run stability and balance relationship are obtained through the appropriate Vector Error Correction Model (VECM). The estimate of the short-run and the adjustment parameters are presented in Table 5.

Table 5: Estimated Short-Run and Error-Correction Results

\begin{tabular}{cccc}
\hline \hline $\begin{array}{c}\text { Dep. Variable } \\
\text { LNPCC }\end{array}$ & Coefficient & Std. Error & t-statistics \\
\hline \hline ECM(-1) & -0.198547 & 0.08725 & $-2.27555^{* *}$ \\
CONST & 0.278901 & 0.09361 & $2.97929^{* *}$ \\
D(LNPCC(-1)) & -0.195757 & 0.22050 & -0.88780 \\
D(LNTIP(-1)) & 0.352225 & 0.20971 & $1.67961^{*}$ \\
D(LNTIM(-1)) & -0.200814 & 0.16532 & -1.21471 \\
D(LNTEM(-1)) & -0.013474 & 0.03434 & -0.39235 \\
D(LNTDG(-1)) & -0.134634 & 0.12108 & -1.11195 \\
D(LNPRR(-1)) & 0.013982 & 0.04611 & 0.30324 \\
\hline R-square & 0.302687 & & \\
F-statistic & 1.240218 & \\
NOTE: **; and **" shows 10\%, and 5\% level of significance. & &
\end{tabular}

The coefficient of the error correction term (ECM [-1]) is negative and statistically significant at five percent (5\%). From economic view point, the ECM (-1) indicates the speed at which the dependent variable responses to shocks in the explanatory variables before returning to its long-run steady state (equilibrium). The negative sign proved that the restoration of the system to its long run state is effective. The coefficient of the error term $(-0.198547)$ indicate a reasonably slow speed of long-run return to equilibrium on year to year basis after short-run shocks. The ECM (-1) result provide a further prove to the cointegration result.

The short-run dynamics results show that all the indirect tax policies which include export taxes ( $\left.\beta_{4}=-0.013474\right)$, import taxes $\left(\beta_{3}=-0.200814\right)$ and taxes on domestic goods and services $\left(\beta_{2}=-0.134634\right)$ are all negative and insignificant. The statistical insignificance of the results imply that the indirect tax policies do not have any real effect on poverty in the short run. The effect of Personal remittances received D (LNPRR (-1)) is positive and also statistically insignificant hence does not have any real effect on poverty in the short run. 
The coefficient of the direct taxes: taxes on income and property $\left(\beta_{1}=0.352225\right)$ on the other hand have a positive and significant effect on poverty at ten percent (10\%) level. The implication is that when these taxes increase in the shortrun, poverty turn to goes up. These is probably because, these taxes are charged on the incomes such as salaries and wages, property gain, land among others. These reduce the relative wealth retained by the individual in the short-run. The reduction in the wealth retained may also reduce the transfers from the middle classes to those in the lower segment of the society. These therefore go a long way to affect savings and wealth accumulation of the individual and have the propensity of making the individual poor in the short-run. Thus, the short run result shows government direct tax policies are anti-poor.

\section{Policy Recommendations}

Despite general public perception and findings of other researchers that domestic indirect taxes such as VAT are antipoor, this study shows that these taxes do not have any significant impact on poverty in Ghana. However, the study recommends that to avoid future deteriorating effect on poverty, government should expand the base of direct taxes instead of increasing domestic indirect tax rates or imposing new taxes in these categories. There should also be a deliberate policy to expand the tax exempt list to include commodities commonly consumed by the poor segment of the society. By this the fiscal challenges facing the nation can be addressed in socially desirable ways by protecting the vulnerable segments of the society.

To reduce the negative impact of import taxes on poverty, the study recommends a deliberate policy to lower import taxes on selected goods commonly consumed by the poor while at the same time raising taxes on luxury goods coupled with promotion of local production through growth of the private sector. The promotion of local production would lead to creation of job and reduction of the nation's import bill while at the same generating revenue through payment of taxes on the employed resources.

Following the outcome that export taxes impact negatively on poverty, the study recommends that government should consider reducing or eliminating export taxes on export of agriculture products. This would be beneficial to the poor especially unskilled labour and farm hands because the export based of the Ghanaian economy is principally agriculture. However, these should not be done in isolation since there are other trade policies especially the policies of importing countries which might restrict the volume of exports from Ghana. Thus, policy measures to eliminate the adverse effect of this tax policy on poverty is vital to the economic development of the nation.

Based on the report that domestic direct taxes impact positively on poverty, the study recommends that more tax revenue can be mobilized through these taxes which would have mitigating effect on the society. This is because the poor in Ghana actually do not pay these taxes. Moreover, these taxes are mobilized from the former sector, which makes its collection cost effective. Furthermore, government should find effective ways of extending its collection to the informal sectors to ensure enough mobilization of revenue.

The study revealed that increase in remittance would reduce poverty by $0.333 \%$. As a result, the study recommends that deliberate policy initiative should be used to promote transfer of resources in the form of remittance (both home and abroad) from the relatively wealthy segment of the society to the relatively poor segment of the society. Generally, the poor have low level of education and income coupled with their inability to pay their wards school fees among other difficulties. Remittances from the well to do and relatives to support the poor would reduce poverty in the country. What needs to be done is how both the state and the private sector would reinvest the remittances received into productive sectors for better growth and poverty reduction. However, it must be noted that remittances can never be an alternative to a sustained economic growth and development which would have a permanent solution to the poverty situation in the country.

\section{Conclusion}

Poverty is a convoluted occurrence based on a grid of interconnecting social, demographic, economic and political elements. Understanding the phenomenon, its extent, nature and determinants are prerequisites for developing effective policy to reduce poverty. Policies that reduce relative wealth of the population can usually be expected to increase poverty.

The study assessed the impact of Ghana's tax policies on poverty to find out whether the consumption taxes have greater impact on poverty than the direct taxes. This was done by estimating the impact of tax policies such as tax on income and properties and import on poverty in a simple regression form. Johansen cointegration technique was used to estimate the coefficients of the variables. The results show that an increase in indirect tax policy rates worsens poverty in 
Ghana in the long run. Direct tax policies on the other hand have extenuating effect on poverty in the long-run and mitigating influence in the short run. The control variable; personal remittances received also have mitigating influence on poverty in the long-run. The study further observed that the impact of the direct tax policy on poverty is less than that of indirect taxes.

Among others, the study recommends that government should take deliberate policy action to reduce the import taxes while at the same time promoting local production through policies that aid the private sector to grow. This would reduce poverty, create employment and generate tax revenue for government through payment of taxes on resources employed.

\section{References}

Abdallah, A. N. (2008). Taxation in Ghana: Principles, Practice and Planning, $2^{\text {nd }}$ ed, Black Mask Limited, Accra-Ghana.

Acharya, C. P., \& Leon-Gonzalez, R. (2013). The Impact of Remittance on Poverty and Inequality: A Micro-Simulation Study for Nepal. Asian Journal of Empirical Research, 3(9), 1061-1080.

Ackah, C., \& Aryeetey, E. (2012). Globalization, trade and poverty in Ghana. IDRC.

Actionaid.org (2014). Investment Incentives in Ghana, retrieved October 8, 2014 from http://www.actionaid.org/ghana/publications/ investment-incentives-ghana.

Arnold, J. (2008). Do Tax Structure Affect Aggregate Economic Growth? Empirical Evidence from a Panel of OECD Countries. OECD Economics Department Working Papers no. 643.

Auerbach, A. J. (1996). Measuring the Impact of Tax reform, National Tax Journal 49(2): 665-673

Baafi, A. A. (2014). GH\$3.2bn lost to tax exemptions, Graphic Business Tuesday October 7 - Monday October 13, 2014 edition page 1.

Balstra, I and Mosioma, A. (2014). Make Tax Fair: Realizing the Tax Potential. Retrieved October 1, 2014 from http://www.maketaxfair. net/make-tax-fair/.

Bhasin, V. K. (2011). Trade Liberalization Financing and its Impact on Poverty and Income Distribution in Ghana. African Economic Research Consortium (AERC), 234. , Nairobi: Kenya.

Bhasin, V. K. \& Annim, S. K. (2005). Impact of Elimination of Trade Taxes on Poverty and Income Distribution in Ghana. Washington DC: IMF

Bird, K. (2008). The political economy of pro-poor growth: The challenge of making growth pro-poor. Overseas development institute (ODI) Briefing Paper 35

Bird, R. M. (2004). Administrative dimensions of tax reform. Asia-Pacific Tax Bulletin, 10(3), 134-50.

Bird, R. M., \& Zolt, E. M. (2011). Dual income taxation: a promising path to tax reform for developing countries. World Development, 39(10), 1691-1703.

Brown, D. (2011). 10 Reasons Why Cutting Poverty is good for our Nation: A Hand up Creates a Stronger and More Vibrant Middle Class. Retrieved May 2, 2015 from https://www.americanprogressaction.org/issues/poverty/news/2011/12/06/10771/10-reasonswhy-cutting-poverty-is-good-for-our-nation/

Caminada, K., Goudswaard, K. Wang, C. (2012). Disentangling Income Inequality and the Redistributive Effect of Taxes and Transfers in 20 LIS Countries over Time. LIS Working Paper Series no.581. Retrieved November 7, 2014 from http://www.lisdatacenter.org/ wps/liswps/581.pdf.

Chinweike (2010). Meaning of tax and taxation - an introduction. Retrieved April 30, 2015 from http://www.taxationtaxlawyer.com/ meaning-of-tax-and-taxation-an-introduction.

Cleveland, H. (2014). 5 effects of poverty. Retrieved May 2, 2015 from http://borgenproject.org/5-effects-poverty/

Cobham, A. (2005). Taxation policy and development. OCGG Economy Analysis, 2, 1-23.

Cohn, S. M. (2007). Reintroducing macroeconomics: a critical approach. ME Sharpe.

Corong, E. L. (2008). Tariff reductions, carbon emissions, and poverty: an economy-wide assessment of the Philippines. ASEAN Economic Bulletin, 25(1), 20-31.

Cororaton, C. B. and Cockburn, J., (2007). Trade reforms and poverty - Lessons from the Philippines: A CGE-microsimulation analysis, Journal of Policy Modeling 29: 141-163.

Dadkhah, K. (2009). The evolution of macroeconomic theory and policy. Springer Science \& Business Media.

Danielson, A. (2001). When do the poor benefit from growth, and why? Lund University.

Dartanto, T. (2010). Volatility of world rice prices, import tariffs and poverty in Indonesia: A CGE-microsimulation analysis. Ekonomi Dan Keuangan Indonesia, 58(3), 335.

Devkota, J. (2014). The impact of migrants remittances on poverty and inequality in Nepal. Forum of international development studies 44.

Duclos, J. Y., Makdissi, P. and Araar, A. (2009). Pro-poor Tax Reforms, with an Application to Mexico, IZA Discussion Paper No. 4511.

Duclos, J. Y., Makdissi, P., \& Wodon, Q. (2008). SOCIALLY IMPROVING TAX REFORMS*. International Economic Review, 49(4), 1505-1537.

Emini, C. A., et al (2005). The poverty impacts of the Doha Round in Cameroon: the role of tax policy. Forth coming from world bank.

Franzsen, R. C. D. (2012). Encouraging Tax Compliance for Improved Revenue Mobilization. Retrieved October 3, 2014 from http://www.taxghana.org/images/franzsen_encouraging_tax_compliance_2012paper1.pdf. 
Grusky, D. and Kanbur, R. (2006). Conceptual Ferment in Poverty and Inequality Measurement: The View from Economics and Sociology. Q-Squared Working Paper No. 21. Retrieved November 8, 2014 from https://www.trentu.ca/ids/documents/Q2_ WP21 GruskyandKanbur.pdf

Gupta, S., Pattillo, C., \& Wagh, S. (2007). Impact of remittances on poverty and financial development in Sub-Saharan Africa. IMF WP $07 / 38$.

Handley, G. et al (2009). Poverty and Poverty Reduction in Sub-Saharan Africa: An Overview of the Issues, Oversea Development Institute Working paper 299.

Hull, K. (2009). Understanding the relationship between economic growth, employment and poverty reduction. Organization for Economic Cooperation and Development (OECD) Promoting pro-poor growth: employment. OECD, 69-94.

Imai, K. S., Gaiha, R., Ali, A., \& Kaicker, N. (2014). Remittances, growth and poverty: New evidence from Asian countries. Journal of Policy Modeling, 36(3), 524-538.

Joumard, I., Mauro, P. and Debbie, B. (2012). Tracking income inequality: The role of taxes and transfers, OECD Journal: Economic Studies, Published online first. Retrieved November 7, 2014 from http://www.oecd.org/eco/public-finance/Tacklingincomein equalityTheroleoftaxesandtransfers.pdf.

Karlan, D., \& Thuysbaert, B. (2013). Targeting ultra-poor households in Honduras and Peru (No. w19646). National Bureau of Economic Research.

Kayaga, L. (2007). Tax Policy Challenges Facing Developing Countries: A case Study of Uganda. A Thesis submitted to the Faculty of Lawfor a Master Degree in Law Queen's University Kingston, Ontario, Canada.

Kefela, T. G. (2009). Reforming Tax Policies and Revenue Mobilization Promotes a Fiscal Responsibility: A Study of East and West African States. Journal of Law and Conflict Resolution 1(5): 098-106.

Leith, et al (2003). Indonesia Rice Tarrif, Poverty and Social Impact Analysis Report. www.prspsnthesis.org/indonesia_Final_PSIA.doc.

Mabugu, R., Fofana, I. and Chitiga, M. (2014). Pro-Poor Tax Policy Changes in South Africa: Potential and Limitations. Retrieved November 11, 2014 from http://aercafricaevents.org/files/Pro-Poor_Tax_Policy_and_Tax_Reform_in_South_Africa_final_27may. pdf.

Moche, T. J., Monkam, N. and Aye, G. C. (2014). Fiscal Decentralization and Poverty in South Africa: Evidence from Panel Data Analysis. Investment Management and Financial Innovations, Vol. 11 Issue 2.

Moore, M. and Schneider, A. (2004). Taxation, governance and poverty: where do the middle income countries fit? OpenDocs at the Institute of Development Studies htt://opendocs.ids.ac.uk

Musgrave, R. A. and Musgrave, P. B. (1989). Public Finance in Theory and Practice, $5^{\text {th }}$ ed. McGraw-Hill Book Company, New York.

Myles, G. (2009). Economic growth and the Role of Taxation-Theory, OECD Economics Department Working Papers, No. 713, OECD Publishing http:dx.doi.org/10.1787/222800633678.

Nogues, J. J (2008). The domestic impact of export restrictions: the case of Argentina, IPC Position Paper - Agricultural and Rural Development Policy series, Washington D.C.: International Policy Council on Food and Agricultural Trade. www.agritrade.org/ EportRestrictions.html.

OECD (2012). Income Inequality and growth: The Role of Taxes and Transfers, OECD Economics Department Policy Notes, no 9. January 2012.

Okine, C. B. (2014). Ghana to reduce heavy rice imports. Retrieved May 1, 2015 from http://graphic.com.gh/business/businessnews/16534-ghana-to-reduce-heavy-rice-imports.html

Okner, B. A. (1975). Individual taxes and the distribution of income. In The Personal Distribution of Income and Wealth (pp. 45-74). NBER.

Oyewo, B. M. (2013). Taxation and tax policy as government strategy tools for Economic development in Nigeria. ISOR Journal of business and management vol 13, issue 5: 34-40.

Pinkovsky, M and Sala-i-Martin, X. (2014). Lights, Camera, Income! Estimating Poverty Using National Accounts, Survey Means and Lights. Federal Reserve Bank of New York Staff Reports No.669, April 2014; revised January 2015.

Prasad, N. (2008). Policies for Redistribution: The Use of taxes and Social transfers. International Institute for Labour Studies Discussion Paper DP/194/2008. Available at SSRN 1358237

Quartey, P., Aidam, P. \& Obeng, C. K. (2007). The Impact of Trade Liberalization on Poverty in Ghana. Retrieved April 15, 2015 from www.gtap.agecon.purdue.edu

Ravallion, M. (1997). Can high-inequality developing countries escape absolute poverty?. Economics Letters, 56(1), 51-57.

Ravallion, M. (2001). Growth, inequality and poverty: looking beyond averages. World development, 29(11), 1803-1815.

Ravallion, M. (2004). Pro-poor growth: A primer. World Bank policy research working paper, (3242).

Romer, D. (2012). Advanced Macroeconomics, $4^{\text {th }}$ ed. McGraw-Hill Companies Inc, New York.

Sehili, S. and Wodon, Q. (2008). Analyzing the Potential Impact of Indirect Tax Reforms on Poverty with Limited Data: Niger, MPRA Paper No. 11074. Downloaded from http://mpra.ub.uni-muenchen.de/11074/.

Sen, A. (1976). Poverty: An Ordinal Approach to Measurement, Econometrica 44 (2): 219-231

Sen, A. (1999). Development as Freedom, Anchor Books, New York

Solow, R. M. (1959). Poverty and economic growth. Focus, 3-5.

Son, H. (2003). Is Thailand's Fiscal System Pro-Poor?: Looking from Income and Expenditure Components. The World Bank.

Subramanian, S. (1997). "Introduction: The Measurement of Inequality and Poverty." The Measurement of Inequality and Poverty. S. Subramanian ed. Readers in Economics. Oxford University Press: Oxford. 
UNDP (1990). Human Development Report 1990, Oxford University Press. Retrieved November 8, 2014 from http://hdr.undp.org/sites/ default/files/reports/219/hdr_1990_en_complete_nostats.pdf

Warr, P. (2002). Export taxes and income distribution: the Philippines coconut levy. Weltwirtschaftliches Archiv Bd. 138, H. 3 (2002) 237458. 